\title{
Hydroalcoholic plant extracts from the southwest Amazon for the alternative control of fall armyworms
}

\author{
Extractos hidroalcohólicos de plantas propias de la Amazonía sur \\ occidental como alternativa de control de la oruga militar tardía
}

\author{
Ana Cláudia Vieira dos Santos ${ }^{1}$, Waldiane Araújo de Almeida ${ }^{1}$, \\ Carromberth Carioca Fernandes ${ }^{1}$, Adalberto Hipólito de Sousa ${ }^{1 *}$
}

\begin{abstract}
RESUMEN
Esta investigación tiene el objetivo de hacer una selección de especies vegetales que son propias de la región Amazónica con potencial de uso en el manejo integrado de la oruga militar tardía Spodoptera frugiperda (J.E. Smith) (Lepidoptera: Noctuidae). Para tal, fue evaluado la eficiencia de extractos hidroalcohólicos de 15 especies vegetales que se son de la región. Los extractos fueron producidos a partir de las hojas, o de la cáscara, o de liana de las plantas. La eficiencia de los extractos ( $\left.30 \mathrm{mg} \cdot \mathrm{mL}^{-1}\right)$ fue evaluada sobre huevos y larvas de $3^{\circ}$ instar de $S$. frugiperda. Se constató una variación de respuesta de la oruga militar tardía entre los extractos hidroalcohólicos. El extracto de la cáscara de Calycophyllum spruceanum (Benth.) Hook. f. ex K. Schum. presentó mayor eficiencia en los huevos, y el extracto de las hojas de Bauhinia forficata Link presentó mayor eficiencia en las larvas. Estos resultados son fundamentales para el manejo de la oruga militar tardía, toda vez que, los efectos nocivos reducen las pérdidas en la producción de maíz en las primeras fases del desarrollo del S. frugiperda. Se concluye que los extractos de C. spruceanum y $B$. forficata fueron los más eficientes para los huevos y larvas de la oruga militar tardía.
\end{abstract}

Palabras clave: Spodoptera frugiperda, insecticidas botánicos, manejo integrado de plagas.

\begin{abstract}
This study aimed to screen plant species from the Amazon region for the potential to be used in the integrated management of the fall armyworm Spodoptera frugiperda (J.E. Smith) (Lepidoptera: Noctuidae). For this purpose, the efficiency of the hydroalcoholic extracts of 15 plant species from the Amazon region was evaluated. The extracts were obtained from plant leaves, bark, or vines. The efficiency of the extracts $\left(30 \mathrm{mg} \cdot \mathrm{mL}^{-1}\right)$ was evaluated on eggs and third instar larvae of $\mathrm{S}$. frugiperda. A range of reactions of the fall armyworm to the hydroalcoholic extracts was observed. The extract obtained from the bark of Calycophyllum spruceanum (Benth.) Hook. f. ex K. Schum. presented the highest efficiency against the eggs, whereas the extract obtained from the leaves of Bauhinia forficata Link was most efficient against the larvae. These findings are essential for the management of fall armyworms because the deleterious effects in the initial stages of $\mathrm{S}$. frugiperda development significantly reduce maize production. In conclusion, the extracts of $\mathrm{C}$. spruceanum and $\mathrm{B}$. forficata were more efficient for eggs and larvae of the fall armyworm, respectively.

Key words: Spodoptera frugiperda, botanical insecticides, integrated pest management.
\end{abstract}

\section{Introduction}

Brazil is one of the world's largest maize producers, with an estimated annual production of 80,052 million tons according to the 7 th survey of Companhia Nacional de Abastecimento for the 2014/2015 harvest season (CONAB, 2015). Maize is economically important because of its diversified uses, ranging from its use in animal feed to that in industries. In low-income regions, $70 \%$ of this cereal and its derivatives are used as the main source of energy (Duarte, 2006).

The fall armyworm Spodoptera frugiperda (J. E. Smith) (Lepidoptera: Noctuidae) is one of the most important pests of maize and can attack the crop from the emergence of seedling until cob formation. Its presence in the early developmental stages of maize can cause high losses in grain yield because of the sensitivity of the plants, which often do not resist predation (Cruz et al., 2013). Considering the

1 Departamento de Ciências Biológicas e da Natureza, Universidade Federal do Acre, Rio Branco, AC, 69920-900,Brazil.

* Corresponding author: adalberto@ufac.br. 
difficulty to control this pest, up to five insecticide applications are made in some regions during the harvest season (Figueiredo et al., 2006). The fall armyworm is typically managed using synthetic insecticides, but their application is often performed continuously and indiscriminately for several years. Consequently, the use of these products has caused environmental contamination and human poisoning and has caused resurgence of some pest species and extinction of natural predators (Lima Júnior et al., 2010), along with selection of resistant insect species (Rodriguez \& Omoto, 2001). An alternative control strategy involves using plant insecticides, with priority to materials obtained from endogenous plant species (Silva et al. 2007; Geris et al., 2008; Sarria et al., 2011; Santos et al., 2011; Prophiro et al., 2012; Silva et al., 2012).

Several plant species synthesize compounds that protect against herbivory, pathogens, and microorganisms (Menezes-Aguiar, 2005). More than 100,000 secondary metabolites with insecticidal properties have been identified, including alkaloids, terpenoids, flavonoids and quinones obtained from approximately 200,000 plant species worldwide (Silva et al., 2012). These compounds have distinct modes of action on insects, including acute toxicity and repellency, as well as inhibition of feeding, growth, development, and reproduction. They are commonly used in the forms of powders, extracts or oils, all of which are easily obtained and generally do not present risks to consumers and operators (Santos et al., 2011; Silva et al., 2012).
Considering the abovementioned information and that northern Brazil is located within the Amazon rainforest, a refuge to the largest plant biodiversity on the planet, the aim of this study was to screen plant species of this region to identify candidates with insecticidal potential against $S$. frugiperda.

\section{Materials and Methods}

\section{Insect rearing}

The bioassays were carried out in the Laboratory of Entomology of the Federal University of Acre, Rio Branco Campus, under constant temperature $\left(25 \pm 2{ }^{\circ} \mathrm{C}\right)$, relative humidity $(70 \pm 5 \%)$ and 12 -h scotophase, using biochemical oxygen demand-type incubators. A stock colony of $S$. frugiperda was established in the laboratory according to the methods of Bavaresco et al. (2002), from specimens from the Agroforestry Research Center of Acre (EMBRAPA/ $\mathrm{AC})$. The caterpillars were fed on a diet composed of ascorbic acid (5.1 g), sorbic acid (1.7 g), agar (15.0 g), distilled water $(1,200.0 \mathrm{~mL})$, beans $(1,665.5 \mathrm{~g}), 10 \%$ formalin $(5.0 \mathrm{~mL})$, wheat germ $(79.2 \mathrm{~g})$, brewer's yeast $(50.7 \mathrm{~g})$, methyl parahydroxybenzoate (nipagin) $(3.2 \mathrm{~g})$, and inhibitor solution $(5.0 \mathrm{~mL})$. The diet was produced according to Kasten Júnior et al. (1978).

\section{Sample extraction}

Extracts were produced from plant leaves, except for Calycophyllum spruceanum (Benth.)

Table 1. List of plant species used for obtaining the hydroalcoholic extracts.

\begin{tabular}{|c|c|c|c|}
\hline $\begin{array}{l}\text { Common } \\
\text { name }\end{array}$ & Scientific name & Family & $\begin{array}{c}\text { Plant } \\
\text { organ used }\end{array}$ \\
\hline Assacu & Hura crepitans L. & Euphorbiaceae & Leaves \\
\hline Aloe & Aloe arborescens Miller & Liliaceae & Leaves \\
\hline Cupuaçu & Theobroma grandiflorum [Willd. Ex Spreng.] Schum. & Sterculaceae & Leaves \\
\hline Graviola & Annona muricata L. & Annoonaceae & Leaves \\
\hline Ingá & Inga spp. & Leguminosae & Leaves \\
\hline Jaca & Artocarpus integrifolia $\mathrm{L}$. & Moraceae & Leaves \\
\hline Jambú & Acmella oleracea $\mathrm{L}$. & Asteraceae & Leaves \\
\hline Jenipapo & Genipa Amaricana L. & Rubiaceae & Leaves \\
\hline Passion Fruit & Passiflora edulis Sims & Passifloraceae & Leaves \\
\hline Mulateiro & Calycophyllum spruceanum (Benth.) Hook. f. ex K. Schum. & Rubiaceae & Bark \\
\hline Mulungu & Erythrina velutina Willd. & Leguminosae & Leaves \\
\hline Oeirana & Salix martiana Leyb. & Salicaceae & Leaves \\
\hline Pata de vaca & Bauhinia forficata Link & Leguminosae & Leaves \\
\hline Rinchão & Stachytarpheta cayennensis (Rich.) Vahl & Verbenaceae & Leaves \\
\hline Timbó & Derris spp. & Fabaceae & Vines \\
\hline
\end{tabular}


Hook. f. ex K. Schum. and Derris sp., for which bark and vines were used, respectively (Table 1). These materials were collected in the municipalities of Rio Branco and Senador Guiomard, Acre, Brazil. The samples were dried at room temperature and transferred to trays covered with newspaper. After drying, the samples were ground in an electric mill and stored in plastic bags for 15 days.

Subsequently, $300 \mathrm{~g}$ of crushed plant material from each sample were added to a glass container containing $1.5 \mathrm{~L}$ of aqueous-alcoholic solution (ethanol:water, 7:3 v/v). The containers were placed in an ultrasonic bath for $2 \mathrm{~h}$ at a power of $90 \mathrm{~W}$ and frequency of $40 \mathrm{kHz}$. The extracted material was filtered using filter paper and the solvent was removed using a rotary evaporator. The extracted material was maintained at room temperature in biosafety cabinets with direct ventilation and stored under refrigeration overnight. The extraction was interrupted when the sample weight remained constant. The crude extracts were collected and the residues were discarded.

To measure the extract concentration (30 $\mathrm{mg} \cdot \mathrm{mL}^{-1}$ ), each crude extract was weighed on an analytical scale and transferred to a glass container capped with a polyvinyl chloride film. The desired concentration was obtained using distilled water, which was added to each crude extract 1 day prior to performing the bioassays to ensure that the extract was thoroughly dissolved.

\section{Bioassays}

The efficiency of the extracts at $30 \mathrm{mg} \cdot \mathrm{mL}^{-1}$ was evaluated on eggs and third instar larvae of $S$. frugiperda. Bioassay were performed in Petri dishes (5.0 cm diameter $\times 1.2 \mathrm{~cm}$ height) containing a filter paper disc moistened with $200 \mu \mathrm{L}$ of each extract; the extract quantity was determined in preliminary tests. Four Petri dishes were used as replicates for each egg bioassay and contained a disc with 40 eggs/ plate. A single larva was used per plate to prevent cannibalism, which is common in this species. Forty larvae were used in each treatment, divided into four replicates of 10 larvae each. A completely randomized design was used. Eggs and larvae were exposed to the extracts for $24 \mathrm{~h}$. Subsequently, the numbers of hatched and unhatched eggs and live and dead larvae were counted. The egg count was repeated daily until the fifth day, as established in the preliminary tests.

\section{Statistical analysis}

The experimental design was completely randomized with four replicates. The efficiency of the treatments compared to the control was calculated using the Abbott formula (Abbott, 1925). The results were subjected to analysis of variance and the means were compared using the Scott-Knott grouping test at a significance level of 5\% (Scott \& Knott, 1974). The analyses were conducted using the Sistema para Análise de Variância software (Ferreira, 2011).

\section{Results and Discussion}

The results of the efficiency of the hydroalcoholic extracts against the eggs and third instar larvae are presented in Figures 1 and 2. The efficiency varied significantly among the extracts; for eggs and larvae it was $0 \%-75 \%\left(\mathrm{~F}_{14 ; 41}=4.51 ; P \leq 4<0.001\right)$ and $0 \%$ $-42.50 \%\left(\mathrm{~F}_{14,41}=6.96 ; P \leq 4<0.001\right)$, respectively. At least one extract showed ovicidal activity and another extract exhibited larvicidal activity, with significantly higher efficiency compared to other plant extracts. The most efficient extract against the eggs was obtained from the bark of $C$. spruceanum and the extract that was most efficient against the larvae was obtained from the leaves of B. forficata Link.

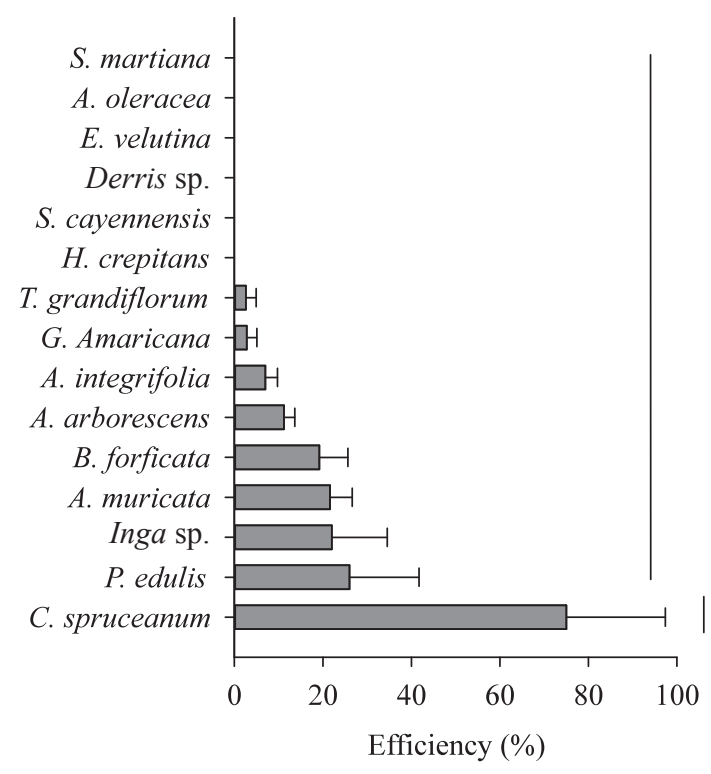

Figure 1. Efficiency of plant extracts against eggs of $S$. frugiperda. Averages grouped with bars at different periods indicate significant differences using the Scott-Knott test $(P<0.05)$. 


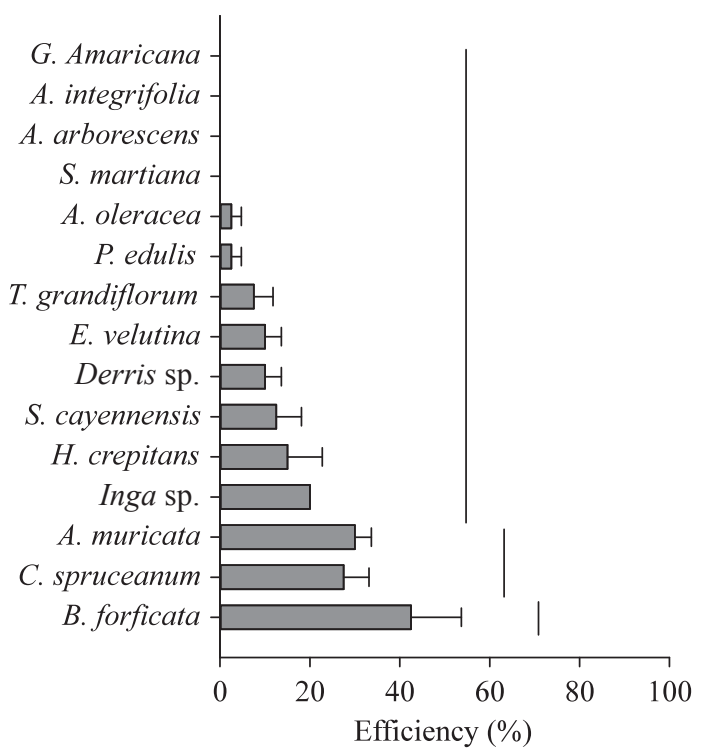

Figure 2. Efficiency of plant extracts against third instar larvae of $S$. frugiperda. Averages grouped with bars at different periods indicate significant differences using the Scott-Knott test $(P<0.05)$.

This study reported for the first time the insecticidal potential of the hydroalcoholic extracts of $C$. spruceanum and B. forficata-common plant species in the southwestern Amazon-against $S$. frugiperda. From a toxicological point of view, the recognition of the insecticidal potential of these plant species is significant because of the range of secondary metabolites often found in hydroalcoholic extracts. These chemical metabolites are not required for the immediate survival of plant cells but confer an evolutionary advantage for their survival and reproduction (Vizzoto et al., 2010); they may also function as natural defense pesticides against herbivores or pathogens (Santos et al., 2011; Silva et al., 2012).

Although this is the first study recording the ovicidal activity of the $C$. spruceanum extract, previous studies have reported the presence of insecticidal compounds, including coumarin, alkaloids, and triterpenes, in other species of the family Rubiaceae (Oliveira et al., 2013); this highlights the importance of fractioning this extract and increased efforts to enhance its activity.
Another important factor related to the insecticidal potential of this extract is that the fall armyworm is difficult to control at the egg stage owing to the presence of a lipid or waxy layer inside the corium with ability to retain toxic substances (Machado et al., 2007).

The insecticidal activity of the B. acuarana extract against larvae of Aedes aegypti has also been reported (Góis et al., 2011; 2013). Thirty compounds were obtained from the essential oil of the leaves of this plant species and the main constituents were sesquiterpenes, spathulenol $(23.4 \% \pm 0.08 \%)$, epi- $\alpha$-cadinol $(20.7 \% \pm 0.12 \%)$, and caryophyllene oxide $(16.4 \% \pm 0.04 \%)$ (Góis et al., 2011). Previous studies on the insecticidal activity of C. spruceanum and B. forficata and of other plant species from the Amazon indicate that the flora of this region has immense potential for the production of secondary compounds with biocidal activity. Notably, the majority of the studies on the insecticidal properties of plants from the Amazon are recent (Silva et al., 2007; Geris et al., 2008; Sarria et al., 2011; Moreno et al., 2011; 2012; Prophiro et al., 2012).

In conclusion, the extracts of $C$. spruceanum and B. forficata were more efficient for eggs and larvae of the fall armyworm, respectively. These results of this study are of fundamental importance for an integrated pest management, considering that deleterious effects in the initial stages of $S$. frugiperda development reduce maize production. Moreover, these results are of considerable economic importance to Amazonian producers, who have low purchasing power, and these plants are essential sources of material for the development of novel insecticidal compounds. However, the plant species evaluated in this study were selected on the basis of their biocidal potential, their taxonomic status (genus/family), or their constituents. According to Tavares \& Vendramim (2005), the availability of active compounds in plants may vary depending on the solvent used in the preparation of the extracts. This finding indicates that the possibility of detecting biocidal activities in these plant species or finding extracts with higher toxicity should not be ignored. 


\section{Literature Cited}

Abbott, W.S.A.

1925. A method of computing the effectiveness of an insecticide. Journal of Economic Entomology, 18: 265-267.

Bavaresco, A.; Garcia, M.S.; Grützmacher, A.D.; Ringenberg, J.F.E.R.

2002. Biologia e exigências térmicas de Spodoptera cosmioides (Walk.) (Lepidoptera: Noctuidae). Neotropical Entomology, 31: 49-54.

CONAB - Companhia Nacional de Abastecimento

Acompanhamento da safra 2014/2015 - $7^{\circ}$ Levantamento de grãos, setembro de 2015. Disponível em http://www.conab. gov.br/. Acessado em: 20 June 2015.

Cruz, I.; Valicente, H.; Viana, A.; Mendes, S.M.

2013. Risco potencial das pragas de milho e sorgo no Brasil. Sete Lagoas: Embrapa Milho e Sorgo. 40 p. (Documentos, 150).

Duarte, J.O.

2006. Introdução e importância econômicado milho. In: Cruz, J.C.; Versiani, R.P.; Ferreira, M.T.R. Cultivo do milho. Sete Lagoas: Embrapa Milho e Sorgo (Documento, 21).

Ferreira, D.F.

2011. Sisvar: a computer statistical analysis system. Ciência e Agrotecnologia, 35: 1039-1042.

Figueiredo, M.L.C.; Martins-Dias, A.M.P.; Cruz, I.

2006. Relação entre a lagarta-do-cartucho e seus agentes de controle biológico natural na produção de milho. Pesquisa Agropecuária Brasileira, 41: 1693-1698.

Geris, R.; Silva, I.G.; Silva, H.H.G.; Barison, A.; Rodrigues-

Filho, E.; Ferreira, A.G.

2008. Diterpenoids from Copaifera reticulata Ducke With larvicidal activity against Aedes aegypti (1.) (Diptera, Dulicidae). Revista do Instituto de Medicina Tropical de São Paulo, 50: 25-28.

Góis, R.W.S.; Sousa, L.M.; Lemos, T.L.G.; Arriaga, A.M.C.; Andrade-Neto, M.; Santiago, G.M.P.; Ferreira, Y.S.; Alves, P.B.; Jesus, H.C.R.

2011. Chemical Composition and Larvicidal Effects of Essential Oil from Bauhinia acuruana (Moric) against Aedes aegypti. Journal of Essential Oil Research, 23: 59-62.

Góis, R.W.S.; Sousa, L.M.; Santiago, G.M.P.; Romero, N.R.; Lemos, T.L.G.; Arriaga, A.M.C.; Braz-Filho, R.

2013. Larvicidal activity against Aedes aegypti of pacharin from Bauhinia acuruana. Parasitology Research, 112: 2753-2757.

Kasten Junior, P.; Precetti, A.A.C.M.; Parra, J.R.P.

1978. Dados biológicos comparativos de Spodoptera frugiperda (J.E. Smith, 1797) em duas dietas artificiais e substrato natural. Revista de Agricultura, 53: 68-78.

Lima Júnior,I.S.; Nogueira, R.F.; Bertoncello,T.F.; Melo, E.P.; Suekane, R.; Degrande, P.E.

2010. Seletividade de inseticidas sobre o complexo de predadores das pragas do algodoeiro. Pesquisa Agropecuária Tropical, 40: 347-353

Machado, L.A.; Silva, V.B.; Oliveira, M.O.

2007. Uso de extratos vegetais no controle de pragas em horticultura. Biológico, 69: 103-106.

Menezes-Aguiar, E.L.

2005. Inseticidas botânicos: seus princípios ativos, modo de ação e uso agrícola. (Documentos, 205).Seropédica: Embrapa Agrobiologia, 58 p.
Moreno, S.C.; Carvalho, G.A.; Picanço, M.C.; Morais, E.G.F.; Benevenute, J.S.; Moreira, M.D.

2011. Lethal and behavioral effects of amazonian plant extracts on leaf-cutting ant (Hymenoptera: Formicidae) workers. Sociobiology, 57: 93-105.

Moreno, S.C.; Carvalho, G.A.; Picanço, M.C.; Morais, E.G.F.; Pereira, R.M.

2012. Bioactivity of compounds from Acmella oleracea against Tuta absoluta (Meyrick) (Lepidoptera: Gelechiidae) and selectivity to two non-target species. Pest Management Science, 68: 386-393.

Oliveira, A.M.; Lemos, R.P.L.; Conserva, L.M.

2013. $\beta$-Carboline alkaloids from Psychotria barbiflora DC. (Rubiaceae). Biochemical Systematics and Ecology, 50: 339-341.

Prophiro, J.S.; Silva, M.A.N.; Kanis, L.A.; Rocha, L.C.B.P.; Duque-Luna, J.E.; Silva, O.S.

2012. First report on susceptibility of wild Aedes aegypti (Diptera: Culicidae) using Carapa guianensis (Meliaceae) and Copaifera sp. (Leguminosae). Parasitology Research, 110: 699-705.

Rodriguez, G.I.D.; Omoto, C.

2001. Herança da resistência de Spodoptera frugiperda (J.E. Smith) (Lepidoptera: Noctuidae) a lambda-cialotrina. Neotropical Entomology, 30: 311-316.

Santos, J.C.; Faroni, L.R.A.; Sousa, A.H.; Guedes, R.N.C.

2011. Fumigant toxicity of allyl isothiocyanate to populations of the red flour beetle Tribolium castaneum. Journal of Stored Products Research, 47(3): 99-104.

Sarria, A.L.F.; Soares, M.S.; Matos, A.P.; Fernandes, J.B.; Vieira, P.C.; Silva, M.F.G.F.

2011. Effect of Triterpenoids and Limonoids Isolated from Cabralea canjerana and Carapa guianensis (Meliaceae) against Spodoptera frugiperda (J. E. Smith). Zeitschrift fur Naturforschung Section c - A Journal of Biosciences, 66: 245-250.

Scott, A.J.; Knott, M.A.A.

1974. cluster analysis method for grouping means in the analysis of variance. Biometrics, 30: 507-512.

Silva, G.N.; Faroni, L.R.A.; Sousa, A. H.; Freitas, R.S.

2012. Bioactivity of Jatropha curcas L. to insect pests of stored products. Journal of Stored Products Research, 48: 111-113.

Silva, H.H.G.; Geris, R.; Rodrigues Filho, E.; Cleonice Rocha, C.; Silva, I.G.

2007. Larvicidal activity of oil-resin fractions from the Brazilian medicinal plant Copaifera reticulata Ducke (Leguminosae-Caesalpinoideae) against Aedes aegypti (Diptera, Culicidae). Revista da Sociedade Brasileira de Medicina Tropical, 40: 264-267.

Tavares, M.A.G.C.; Vendramim, J.D.

2005. Bioatividade da Erva-de-Santa-Maria, Chenopodium ambrosioides L., Sobre Sitophilus zeamais Mots. (Coleoptera: Curculionidae). Neotropical Entomology, 34: 319-323.

Vizzoto, M.; Krolow, A.C.; Weber, G.E.B.

2010. Metabólitos secundários encontrados em plantas e sua importância. Documento: Embrapa Clima Temperado, 316: 7-15. 
